\title{
CHARACTERIZATION OF TENDON CELL CULTURES OF THE HUMAN ROTATOR CUFF
}

\author{
S. Pauly ${ }^{1}$, F. Klatte ${ }^{1,2}$, C. Strobel ${ }^{1,2}$, G. Schmidmaier ${ }^{1}$, S. Greiner ${ }^{1}$, M. Scheibel $^{1}$ and B. Wildemann ${ }^{1,2 *}$ \\ ${ }^{1}$ Julius Wolff Institut, Center for Musculoskeletal Surgery, and \\ ${ }^{2}$ Berlin-Brandenburg Center for Regenerative Therapies, \\ Charité - Universitätsmedizin Berlin, Germany
}

\begin{abstract}
Rotator cuff tears are common soft tissue injuries of the musculoskeletal system that heal by formation of repair tissue and may lead to high retear rates and joint dysfunction. In particular, tissue from chronic, large tendon tears is of such degenerative nature that it may be prone to retear after surgical repair. Besides several biomechanical approaches, biologically based strategies such as application of growth factors may be promising for increasing cell activity and production of extracellular tendon matrix at the tendon-to-bone unit. As a precondition for subsequent experimental growth factor application, the aim of the present study was to establish and characterize a human rotator cuff tendon cell culture.

Long head biceps (LHB)- and supraspinatus muscle (SSP)- tendon samples from donor patients undergoing shoulder surgery were cultivated and examined at the RNA level for expression of collagen type-I, -II and -III, biglycan, decorin, tenascin-C, aggrecan, osteocalcin, tenomodulin and scleraxis (by Real-time PCR). Finally, results were compared to chondrocytes and osteoblasts as control cells.

An expression pattern was found which may reflect a human rotator cuff tenocyte-like cell culture. Both SSP and LHB tenocyte-like cells differed from chondrocyte cell cultures in terms of reduced expression of collagen type-II $(p \leq 0.05)$ and decorin while higher levels of collagen typeI were seen $(p \leq 0.05)$. With respect to osteoblasts, tenocytelike cells expressed lower levels of osteocalcin $(p \leq 0.05)$ as well as tenascin $\mathrm{C}$, biglycan and collagen type-III. Expression of scleraxis, tenomodulin and aggrecan was similar between all cell types.

This study represents a characterization of tenocytelike cells from the human rotator cuff as close as possible. It helps analyzing their biological properties and allows further studies to improve production of tendon matrix and osteofibroblastic integration at the tendon-bone unit following tendon repair.
\end{abstract}

Keywords: Rotator cuff, tendon healing, tenocyte, tendonlike cells, cell culture, tendon-bone.

*Address for correspondence:

Britt Wildemann

Julius Wolff Institut

Center for Musculoskeletal Surgery

Charité-Universitätsmedizin Berlin

Augustenburger Platz 1, 13353 Berlin, Germany

Telephone Number: +49 -30 - 450559618

FAX Number: +49 -30 - 450559938

E-mail: britt.wildemann@charite.de

\section{Introduction}

Rotator cuff tendon injuries cause pain and disability. Although surgical approaches may provide good and excellent results in many patients (Severud et al., 2003; Wolf et al., 2004; Baysal et al., 2005), the main complication remains non-healing or retear of the tendon from its humeral footprint. Retears occur in up to $94 \%$ of cases and depend on several variable issues such as demographic factors, size of the initial tear, biologic characteristics (fatty infiltration, tendon tissue quality) and biomechanical aspects of the chosen surgical technique (Boileau et al., 2005; Bishop et al., 2006; Cole et al., 2007) The natural history of retears or recurrent defects remains unknown. The therapeutic aim of rotator cuff surgery represents a secure and durable tendon-to-bone regeneration.

To improve outcome results, biomechanical approaches for new surgical techniques have led to increased use of strong synthetic materials in order to reattach the torn tendon stump (Mahar et al., 2007; Lorbach et al., 2008; Pauly et al., 2010). However, the assumption of tissue damage and tendon strangulation through strong tissue adaption to the bony insertion is possible and might even deteriorate regeneration (Gerber et al., 1994; Flatow, 1996).

Biologically based strategies to stimulate cell activity and production of extracellular tendon matrix proteins have received increasing attention (Maffulli et al., 2002; Hsu and Chang, 2004). Since tenocytes exhibit very low proliferative capacity (Chuen et al., 2004), one possible approach for improved tendon healing is to assess their biological activity under the influence of growth factors. The latter are considered to accelerate ligament and tendon-to-bone healing (Molloy et al., 2003; Hsu and Chang, 2004; Angel et al., 2006) by increasing fibroblast proliferation, the synthesis of extracellular matrix (ECM) proteins, and revascularization (Lee et al., 1995; Batten et al., 1996; Marui et al., 1997; Thomopoulos et al., 2007; Chang et al., 2000; Takahasih et al., 2002).

Tendon cell cultures represent a precondition for studies on their biology and influence of growth factors. Hence, numerous studies have been carried out on tendon cell cultures from tissue samples of human or animal origin that were subsequently studied. However, many studies lack a specific characterization of the obtained cell cultures. Reviewing the current literature, the presence of tenocytes was assumed by phenotypic criteria or proof of collagen type-I (COL-I) (Thomopoulos et al., 2005; Costa et al., 2006; Anitua et al., 2006; Mazzocca et al., 2007) which cannot be considered tendon specific. Other studies furthermore assessed COL-III (Maffulli et al., 
2000; Takahasih et al., 2002; Yang et al., 2004; de Mos et al., 2008) or proteins such as decorin and biglycan (Kardestuncer et al., 2006; Yao et al., 2006; Rios et al., 2007; Fu et al., 2008) which are non-specific tendon proteoglycans (Rees et al., 2000; Yoon and Halper, 2005) and are initially increased after experimental tendon detachment (in rodents) (Yokota et al., 2005).

The possibly tendon specific gene Scleraxis (Schweitzer et al., 2001; Edom-Vovard et al., 2002) was described for characterization of cells isolated from human or rodent tendon (Salingcarnboriboon et al., 2003; SchulzeTanzil et al., 2004). Only few studies looked into characterization more detailed and described the expression of several markers such as COL-I, -III, decorin, COMP, aggrecan, elastin and scleraxis (Stoll et al., 2010) or COL-I, -II, scleraxis, fibronectin, proteoglycan and $\beta 1$ integrin (Schulze-Tanzil et al., 2004).

In the present approach, cells were isolated from human rotator cuff tissue samples, cultivated and subsequently screened for several markers. These markers were COL-I (main component of extracellular tendon matrix (Blevins et al., 1997; Kannus, 2000)), COL-III (increased in early tendon healing (Takahasih et al., 2002) and experimentally in chronic tears (Yokota et al., 2005)), decorin (most important proteoglycan in tendon (Rahaman and Mao, 2005; Yoon and Halper, 2005)) and biglycan (a proteoglycan present in tendon, cartilage and bone (Yoon and Halper, 2005)), aggrecan (a proteoglycan, present in cartilage as well as in compressed tendon regions (Rees et al., 2000), and tenascin C (a glycoprotein, part of tendon cell adaptation to compression (Martin et al., 2003)).

Cultures were furthermore screened for scleraxis (a transcription factor and possibly a tendon specific marker (Schweitzer et al., 2001)), tenomodulin (a transmembrane glycoprotein, possibly another tendon-specific marker (Jelinsky et al., 2010)), COL-II (cartilage specific) and osteocalcin (the major non-collagen protein in the bone matrix, bone-specific), to separate the tenocyte-like cells from other cell types of the musculoskeletal tissues.

The aim of the present study was to establish and characterize a human rotator cuff tenocyte-like cell culture in order to allow subsequent systematic studies on their biological response to growth factors.

\section{Materials and Methods}

\section{Tendon material, donor patient demographics}

Tendon samples were obtained from patients undergoing arthroscopic surgery for rotator cuff repair or open shoulder surgery such as hemiarthroplasty following humeral head fractures. Prior to biopsy, all patients gave their written informed consent. Tissue samples from the supraspinatus muscle (SSP, $n=11$ ) and the tendon of the long head of the biceps muscle (LHB, intraarticular aspect, $n=7$ ) were obtained.

\section{Patient demographics and clinical data}

SSP tenocyte-like cells ( $\mathrm{n}=11$ samples: 8 male, 3 female, mean age 63.7 yrs, range $32-85 y r s$ ):
- Tendon retraction according to Patte: grade 0-3 (Patte, 1990)

- Fatty infiltration of the SSP muscle: grade I-III according to Goutallier (Goutallier et al., 1994)

- Tear size according to Bateman: stage I-IV (Bayne and Bateman, 1984).

LHB tenocyte-like cells ( $\mathrm{n}=7$ samples: 5 male, 2 female, mean age 59.3yrs, range 23-79 yrs).

Exclusion criteria for LHB-samples were macroscopic evidence of chronic inflammation/tendinitis. LHB-samples were obtained during hemiarthroplasty or tenotomy/ tenodesis following a failed SLAP-repair. 2 LHB-biopsies were obtained during repair/-debridement of concomitant (massive) rotator cuff and pulley-defects.

All biopsies were obtained 3-5 $\mathrm{mm}$ from the torn proximal tendon edge.

\section{Tendon cell cultures:}

Cells were isolated from tissue samples by washing several times with phosphate buffered saline (PBS) $+1 \%$ penicillin/ streptomycin, dissection into small pieces and incubation with $0.3 \%$ collagenase type CLS II in PBS with $\mathrm{Ca} / \mathrm{Mg}$ for 2 hours at $37^{\circ} \mathrm{C}$. The digested tendon material was then placed in a tissue culture flask and cultured in DMEM / HAM's F12 (1:1) supplemented with 10\% foetal calf serum (FCS) and 1\% penicillin/streptomycin.

Cells were incubated at $37^{\circ} \mathrm{C}, 95 \%$ humidity and $5 \%$ carbon dioxide with a change of medium every 2-3 days. As soon as cultured cells reached $80-90 \%$ confluence, they were treated with $0.05 \%$ trypsin $/ 0.02 \%$ ethylenediaminetetraaciticacid (EDTA) and subcultured at a density of $1-1.5 \times 10^{4}$ cells $/ \mathrm{ml}$, maximum until passage 3 (about 8 weeks).

\section{Chondrocyte and osteoblast cultures}

Primary human chondrocytes $(n=3)$ and osteoblasts $(n=3)$ served as control for marker expression and immunocytochemical staining. All patients gave their written informed consent prior to cell culture.

Primary human chondrocyte cultures were kindly provided by Dr. Ringe, Department of Tissue Engineering, Berlin-Brandenburg Centre for Regenerative Therapies. Chondrocytes were cultured in DMEM / HAM's F12 (1:1) supplemented with $10 \%$ FCS and $1 \%$ penicillin/ streptomycin under the same conditions as described above. Chondrocytes were used for experiments at early passages (up to passage 2) to avoid dedifferentiation.

Primary human osteoblasts were isolated as described previously (Robey and Termine, 1985). The osteoblasts were cultured in MEM EARLE / HAM's F12 supplemented with $10 \% \mathrm{FCS}, 1 \%$ penicillin/streptomycin, $0.05 \mathrm{mM} \beta$-glycerophosphate and $0.05 \mathrm{mM}$ L-ascorbate2-Phosphate under the same conditions as described for tenocytes. Osteoblasts were used up to passage 4.

All cell culture media and supplements were obtained from Biochrom AG, Berlin, Germany.

Real-time Polymerase Chain Reaction (RT-PCR)

RNA from about $1-2 \times 10^{5}$ cells of the tenocyte-like cells, chondrocytes and osteoblasts was extracted with the 
Table 1. Primer sequences of target genes for RT-PCR.

\begin{tabular}{|c|c|c|c|}
\hline Target Gene & $\begin{array}{l}\text { Product } \\
\text { size }\end{array}$ & $\begin{array}{l}\text { Annealing } \\
\text { Temperature }\end{array}$ & Sequence \\
\hline $\begin{array}{l}\text { GAPDH } \\
\text { (TIB Molbiol) }\end{array}$ & $111 \mathrm{bp}$ & $59.9^{\circ} \mathrm{C}-66^{\circ} \mathrm{C}$ & $\begin{array}{l}\text { Forward: 5' CCATGAGAAGTATGACAACAGCC 3' } \\
\text { Reverse: 5' CСТTCCACGATACCAAAGTTG 3' }\end{array}$ \\
\hline $\begin{array}{l}\text { Aggrecan } \\
\text { (Neumann et al., 2007) }\end{array}$ & $146 \mathrm{bp}$ & $64.2^{\circ} \mathrm{C}$ & $\begin{array}{l}\text { Forward: 5' CCAGTGCACAGAGGGGTTTG 3' } \\
\text { Reverse: }\end{array}$ \\
\hline $\begin{array}{l}\text { Biglycan } \\
\text { (Rees et al., 2000) }\end{array}$ & $165 \mathrm{bp}$ & $64.2^{\circ} \mathrm{C}$ & $\begin{array}{l}\text { Forward: 5' AGGCCCTCGTCCTGGTGAACA 3' } \\
\text { Reverse: 5' GGATGCGGTTGTCGTGGATGC 3' }\end{array}$ \\
\hline $\begin{array}{l}\text { Decorin } \\
\text { (Primer 3) }\end{array}$ & $205 \mathrm{bp}$ & $64.2^{\circ} \mathrm{C}$ & $\begin{array}{ll}\text { Forward: 5' CGCCTCATCTGAGGGAGCTT 3' } \\
\text { Reverse: 5' TACTGGACCGGGTTGCTGAA 3' }\end{array}$ \\
\hline $\begin{array}{l}\text { COL-I } \\
\text { (Primer 3) }\end{array}$ & $197 \mathrm{bp}$ & $64.2^{\circ} \mathrm{C}$ & $\begin{array}{l}\text { Forward: 5' TGACCTCAAGATGTGCCACT 3' } \\
\text { Reverse: 5' ACCAGACATGCCTCTTGTCC-3' }\end{array}$ \\
\hline $\begin{array}{l}\text { COL-II } \\
\text { (Primer 3) }\end{array}$ & $162 b p$ & $66^{\circ} \mathrm{C}$ & $\begin{array}{ll}\text { Forward: 5' CGCACCTGCAGAGACCTGAA 3' } \\
\text { Reverse: }\end{array}$ \\
\hline $\begin{array}{l}\text { COL-III } \\
\text { (Primer 3) }\end{array}$ & 199 bp & $64.2^{\circ} \mathrm{C}$ & $\begin{array}{l}\text { Forward: 5' GCTGGCATCAAAGGACATCG 3' } \\
\text { Reverse: 5' TGTTACCTCGAGGCCCTGGT 3', }\end{array}$ \\
\hline $\begin{array}{l}\text { Osteocalcin } \\
\text { (Primer 3) }\end{array}$ & 209 bp & $64.2^{\circ} \mathrm{C}$ & $\begin{array}{l}\text { Forward: 5' CCCAGGCGCTACCTGTATCAA 3' } \\
\text { Reverse: 5' CTGGAGAGGAGCAGAACTGG 3' }\end{array}$ \\
\hline $\begin{array}{l}\text { Tenascin C } \\
(\text { Primer } 3)\end{array}$ & $223 \mathrm{bp}$ & $64.2^{\circ} \mathrm{C}$ & $\begin{array}{ll}\text { Forward: 5' TTCACTGGAGCTGACTGTGG 3' } \\
\text { Reverse: } & \text { 5' TAGGGCAGCTCATGTCACTG 3' } \\
\end{array}$ \\
\hline $\begin{array}{l}\text { Tenomodulin } \\
\text { (Itaya et al., 2009) }\end{array}$ & $170 \mathrm{bp}$ & $59.9^{\circ} \mathrm{C}$ & $\begin{array}{ll}\text { Forward: } & \text { 5' TTGAAGACCCACGAAGTAGA 3' } \\
\text { Reverse: } & \text { 5' ATGACATGGAGCACACTTTC 3' } \\
\end{array}$ \\
\hline Scleraxis & $85 \mathrm{bp}$ & $59.9^{\circ} \mathrm{C}$ & $\begin{array}{l}\text { Quiagen (QuantiTect Primer Assay Kit SCXB, } \\
\text { commercial product - no sequence available) }\end{array}$ \\
\hline
\end{tabular}

RNeasy Mini Kit (Quiagen, Hilden, Germany) following the manufacturer's manual and then reverse transcribed into cDNA. RNA concentration was measured with the Nanodrop ND-1000 Spectrophotometer (PeqLab, Erlangen, Germany). A thermocycler (Eppendorf, Hamburg, Germany) was used for cDNA synthesis.

$100 \mathrm{ng}$ of RNA, $1 \mu \mathrm{L} 10 \mathrm{mM}$ Deoxynucleotidetriphosphate (dNTP)-mix (Invitrogen, Darmstadt, Germany) and $1 \mu \mathrm{L}$ Randomprimer (Invitrogen) were filled up to $10 \mu \mathrm{L}$ with aqua ad iniectabilia (Braun, Germany) and incubated for 5 minutes at $65^{\circ} \mathrm{C}$. After incubation on ice $9.5 \mu \mathrm{L}$ reaction-mix consisting of $4 \mu \mathrm{L}$ M-MLV RT $5 \mathrm{x}$ Reactionbuffer (Promega, Mannheim, Germany), $1 \mu \mathrm{L}$ RNase-inhibitor (40 U/ $\mu \mathrm{L}$, Promega) und $4.5 \mu \mathrm{L}$ aqua ad iniectabilia were added and incubated for 2 minutes at $42^{\circ} \mathrm{C}$. $1 \mu \mathrm{L}$ M-MVL RT(H-) (200 U/ $\mu \mathrm{L}$, Promega) was added and incubated for 50 minutes at $42^{\circ} \mathrm{C}$, then samples were cooled down and $1 \mu \mathrm{L}$ RNase H $(1.5 \mathrm{U} / \mu \mathrm{L}$, Promega) was added and incubated for 20 minutes at $37^{\circ} \mathrm{C}$.

The following primers were used for RT-PCR: GAPDH (housekeeping gene, serving as reference), aggrecan, biglycan, COL-I, -II, -III, decorin, osteocalcin, scleraxis, tenascin $\mathrm{C}$, tenomodulin. Most primer sequences were designed using the Primer 3 software, some sequences were adapted from other publications (Table 1). All primers, except Scleraxis, were produced by Tib Molbiol, Berlin, Germany.

The RT-PCR was performed with the iCycler iQ5 RTPCR System and the Bio-Rad iQ5 software (Bio-Rad Laboratories, Munich, Germany). The cDNA was diluted 1:10 and $2 \mu \mathrm{L}$ were pipetted at each well as PCR Template. The mastermix was prepared with the following components for one well: $12.5 \mu \mathrm{L}$ iQSupermix (Bio-Rad),
$1 \mu \mathrm{L}$ primermix (10 $\mu \mathrm{M}$, forward and reverse Primer $1: 1)$, $1 \mu \mathrm{L}$ SYBR Green (Invitrogen) and $8.5 \mu \mathrm{L}$ aqua ad iniectabilia. $23 \mu \mathrm{L}$ of the mastermix were added to each well. The following RT-PCR protocol was used for the amplification: denaturation program $\left(95^{\circ} \mathrm{C}\right.$ for 3 minutes $)$ amplification program was repeated for 40 cycles $\left(94^{\circ} \mathrm{C}\right.$ for $30 \mathrm{~s}, 59.9^{\circ} \mathrm{C} / 64.2^{\circ} \mathrm{C} / 66^{\circ} \mathrm{C}$ for $30 \mathrm{~s}, 72^{\circ} \mathrm{C}$ for $30 \mathrm{~s}$ ), melting curve program $\left(55-95^{\circ} \mathrm{C}\right.$ with a temperature change of $0.5^{\circ} \mathrm{C}$ holding for $30 \mathrm{~s}$ ) and finally a cooling step at $15^{\circ} \mathrm{C}$. The RT-PCR results were analysed with the Bio-Rad iQ5 Software by calculating the ratio of target gene versus GAPDH gene.

\section{Immuncytochemical Scleraxis staining}

The tenocyte-like cells, chondrocytes and osteoblasts were seeded into 4-well chamber slides with a concentration of $2 \times 10^{4}$ vital cells $/ \mathrm{ml}$ ( $1 \mathrm{~mL} /$ well), until they reached $80 \%$ confluence. The cells were fixed for 5 minutes at room temperature in $3.7 \%$ formaldehyde in PBS. The cells were permeabilized using $1 \%$ Triton-X-100 in PBS for 15 minutes at room temperature. After incubation with normal goat serum (Vector Labs, Loerrach, Germany), the cells were stained with primary antibodies for Scleraxis (rabbit polyclonal anti SCXA, $4 \mu \mathrm{g} / \mathrm{mL}$, Abcam, Cambridge, MA, USA) overnight at $4^{\circ} \mathrm{C}$. Negative control was prepared by omitting the primary antibody. The cells were washed with PBS and the biotinylated anti-rabbit IgG antibody was used and subsequently incubated with the Vectastain ABC AP Kit (Vector Labs) for 50 minutes. Cells were then incubated with chromogen buffer ( $\mathrm{pH}$ 8.2) for 10 minutes. The Vector Red Alkaline Phosphatase Substrate Kit (Vector Labs) was used and the reaction developed under visual control. The reaction was stopped with PBS and few drops 


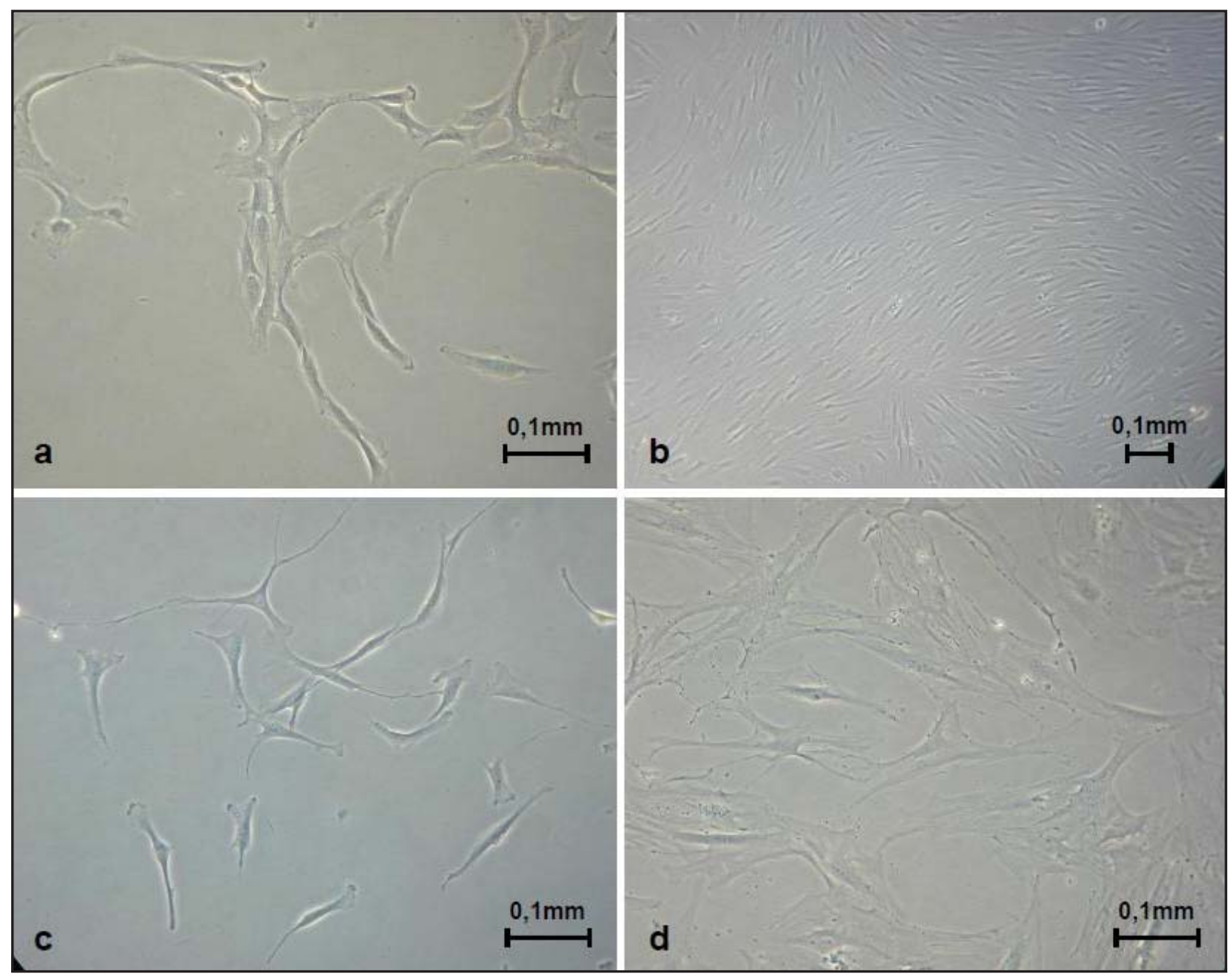

Fig. 1. Culture morphology of tenocyte-like cells from SSP tendon in monolayer culture. (a) chain formation of spindle shaped cells, Passage 0, 9 days after isolation, (b) colony formation, Passage 0, 17 days after isolation, (c) spindle shaped cells, Passage 1, 1 day after subcultivation, (d) cells with wing-like shape, Passage 1, 7 days after subcultivation. From passage 0 to 1 , cells lost the appearance of colony formation and became larger.

of Kaisers Glyceringelatine (Merck, Darmstadt, Germany) were added to the cells that were subsequently covered with a glass coverslip.

\section{Statistics}

Statistical analysis was performed using SPSS 14 for Windows (SPSS Inc, Chicago, IL, USA). The Kruskal Wallis test was used to analyze significant differences between all groups. The Mann-Whitney-U test was performed for non-parametric comparison of two groups. Level of significance was set up at $p \leq 0.05$. To adjust the $\alpha$-Value, the Bonferroni-Holm-Correction was performed.

\section{Results}

\section{Cell culture}

Tenocyte-like cells proliferated to $80-90 \%$ confluence approximately within 14 days. The isolated cells exhibited a spindle shape and particularly built reticular colonies in cell chains (Fig. 1a, b). After subculture, the cells lost this appearance. Partially they became larger and built winglike shapes (Fig. 1c, d).

\section{RT-PCR}

Analysis of different markers by RT-PCR demonstrated an obvious dissociation of tenocyte-like cells from chondrocytes and osteoblasts. In general, data suggest that tenocyte-like cells from either SSP or LHB origin have comparable expression patterns for all analysed markers.

COL-I and -III gene expression showed differences in tenocyte-like cells from SSP and LHB tendon compared to chondrocytes and osteoblasts.

The tenocyte-like cells isolated from the SSP and LHB tendons expressed COL-I in a comparable amount. The osteoblasts showed the highest COL-I expression compared to the other cell types. A very low COL-I expression was found for the chondrocytes, which was significantly below SSP $(p=0.016)$ and LHB $(p=0.017)$ tenocyte-like cells and osteoblasts $(p=0.05)$ (Fig. $2 a)$.

COL-III expression was detected in all investigated cell types and was highest in osteoblasts. However, expression was not differing significantly (Fig. 2b).

\section{Proteoglycans and glycoproteins}

A slight increase of decorin expression was observed for chondrocytes when compared to tenocyte-like cells and 

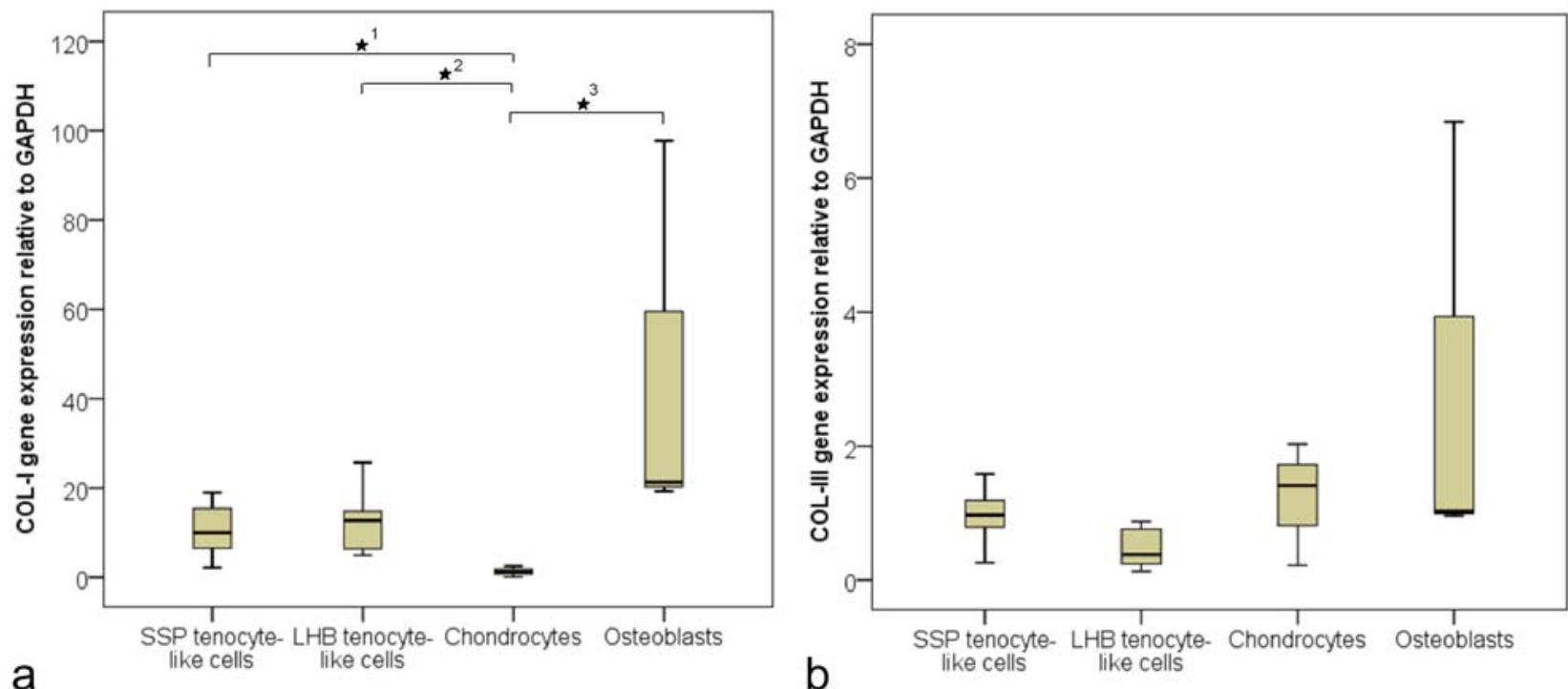

Fig. 2. Real-time quantitative polymerase chain reaction of collagens relative to GAPDH and respective tissue origin of cell cultures of SSP tenocyte-like cells $(n=11)$, LHB tenocyte-like cells $(n=7)$, chondrocytes $(n=3)$ and osteoblasts $(\mathrm{n}=3) ; * p \leq 0.05$; (a) COL-I expression of reference chondrocytes differed significantly to SSP tenocyte-like cells $\left(p^{1}=0.016\right)$, LHB tenocyte-like cells $\left(p^{2}=0.017\right)$ and osteoblasts $\left(p^{3}=0.05\right) ;(\mathbf{b})$ COL-III expression showed no significant differences between the cells types. Osteoblasts served as reference group for statistical analysis.

to osteoblasts. Expression of decorin was similar between tenocyte-like cells and osteoblasts (Fig. 3a).

The expression of biglycan was comparable between chondrocytes and tenocyte-like cells. A marginal increase of its expression was found for osteoblasts (Fig. 3b). The difference was significant compared to SSP tenocyte-like cells after Mann-Whitney-U-Testing $(p=0.036)$ but not when adjusted by Bonferroni-Holm-Correction.

Expression of aggrecan was slightly elevated in chondrocytes compared to tenocyte-like cells from LHB and SSP tendon as well as to osteoblasts $(p>0.05$ each, Fig. 3c).

Osteoblasts showed higher expression of tenascin C compared to tenocyte-like cells and to chondrocytes ( $p>0.05$ each, Fig. $3 d$ ).

\section{Cartilage, bone and tendon markers}

A very low level of COL-II expression was measured for tenocyte-like cells and osteoblasts. Its expression in chondrocytes was significantly higher compared to the other cell types (SSP: $p=0.01$; LHB: $p=0.014$; osteoblasts: $p=0.046$, Fig. 4a)

Regarding bone markers, osteocalcin showed significantly higher expression in osteoblasts when compared to SSP tenocyte-like cells $(p=0.009)$, LHB tenocyte-like cells $(p=0.017)$ and chondrocytes $(p=0.05)$ (Fig. 4b).

Scleraxis expression was low in all three cell types and no significant differences were observed (Fig. 4c).

Expression of tenomodulin was very low and almost similar in all cell types without significant differences (Fig. $4 d)$.

In summary, both SSP and LHB tenocyte-like cells differed from chondrocyte cell cultures in terms of significantly reduced expression of COL-II and lower decorin expression while significantly higher COL-I-levels were seen.
With respect to osteoblasts, tenocyte-like cells expressed significantly lower levels of osteocalcin as well as reduced tenascin $\mathrm{C}$, biglycan and collagen type-III.

\section{Immunocytochemical scleraxis staining}

In order to confirm RT-PCR results for the possible tendon specific marker scleraxis, SSP tenocyte-like cells, chondrocytes and osteoblasts were immunocytochemically stained for scleraxis. The staining showed high positive findings in all cell types. No visible distinctions in intensity between the cell types could be detected (Fig. 5 a-c). For the negative control cells, no staining could be detected (Fig. 5b, data of negative osteoblast and chondrocyte control not shown).

\section{Discussion}

Following surgical rotator cuff repairs, retear or nonhealing of the tendon is a relevant clinical problem (Boileau et al., 2005; Cole et al., 2007; Lafosse et al., 2007). Besides biomechanical improvements (Lorbach et al., 2008; Mahar et al., 2007; Pauly et al., 2010), recent approaches have suggested an influence of growth factors on tendon cell behaviour and their potential value in rotator cuff repair.

Numerous studies on cell cultures from human tendon tissue were carried out (Table 2). Few of these surveys focus on cells from human rotator cuff tissue (Gumina et al., 2009; Takahasih et al., 2002; Tempfer et al., 2009). However, many of these studies lack characterizations that allow the specific assumption of tendon cells. In particular, phenotypic assessment or proof of different collagen-types (Gumina et al., 2009; Li et al., 2008; Maffulli et al., 2000; Takahasih et al., 2002; Yang et al., 2004) are not precise enough as these are expressed in various fibroblastdependent conjunctive tissues. A similar situation is the 

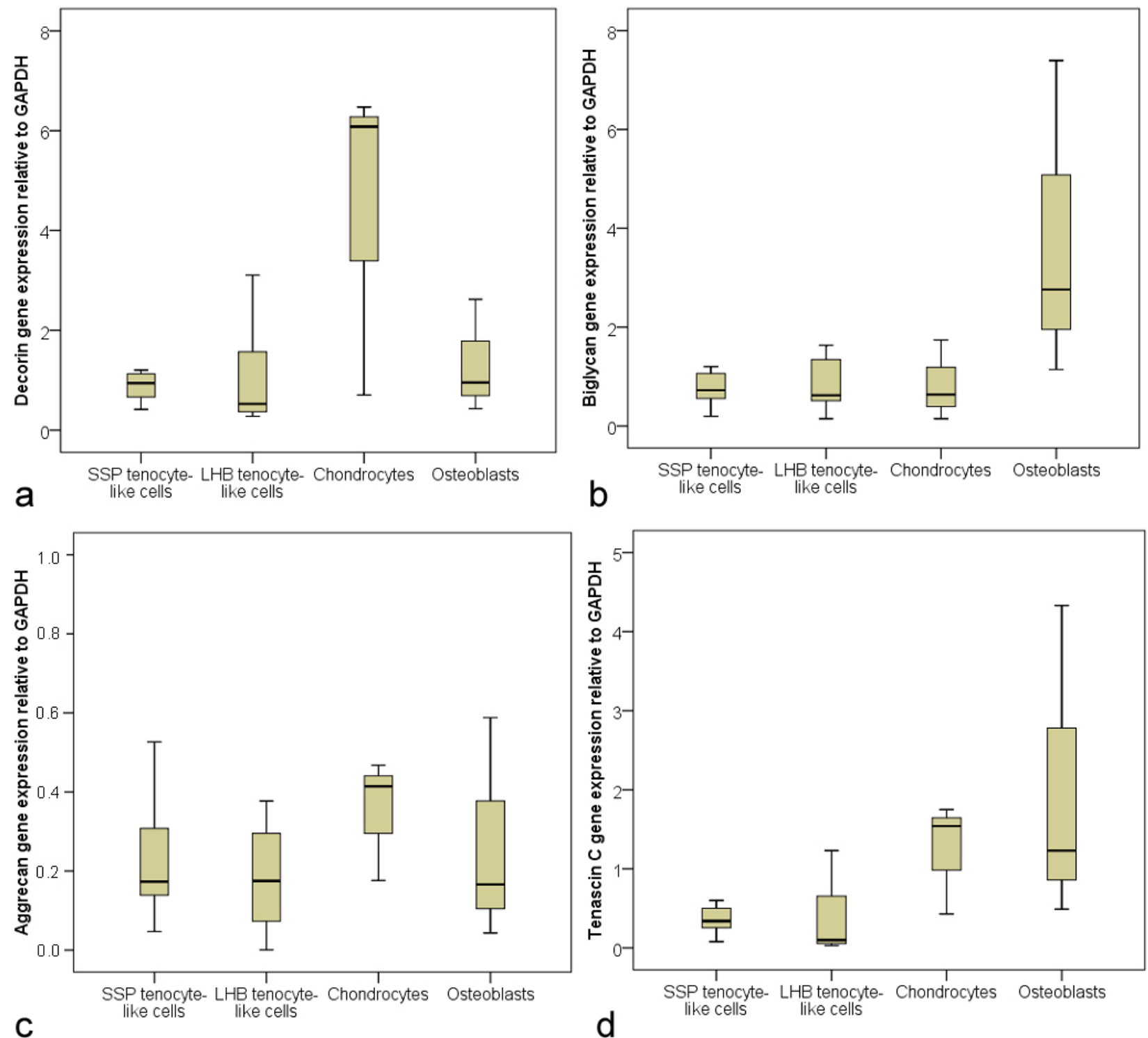

Fig. 3. Real-time quantitative polymerase chain reaction of proteoglycans and glycoproteins relative to GAPDH and respective tissue origin of cell cultures of SSP tenocyte-like cells $(n=11)$, LHB tenocyte-like cells $(n=7)$, chondrocytes $(n=3)$ and osteoblasts $(n=3) ; * p \leq 0.05$. (a) Decorin expression of tenocyte-like cells and osteoblasts did not differ significantly from reference chondrocytes. (b) Biglycan expression of reference osteoblasts showed no significant differences compared to the other cell types. (c) Aggrecan expression showed no significant differences between the cell types. Chondrocytes served as reference group for statistical analysis. (d) Tenascin-C expression without significant differences of the cell types compared to osteoblast reference group.

examination of growth factors expressed in vitro (Anitua et al., 2006; De Mos et al., 2008), Matrix metalloproteinases (MMP) (Tempfer et al., 2009) or surface clusters of differentiation (Scutt et al., 2008) which are not specific for tendon tissue. Other authors assessed the presence of possibly tendon specific gene markers (Schulze-Tanzil et al., 2004) or non specific proteoglycans (Kardestuncer et al., 2006) while characterization of tendon cells obtained for further experiments was not described in some studies (Mazzocca et al., 2007; Wang et al., 2008). A characterization of the cultured cells therefore seems mandatory as a precondition for subsequent investigations of their biology.

The aim of the present study was to characterize tenocyte-like cells from the human rotator cuff as precisely as possible using a spectrum of tendon markers on geneand protein-base. Furthermore, tenocyte-like cells were compared to other cell types of the musculoskeletal system such as osteoblasts and chondrocytes. The majority of cells within healthy tendon tissue cells are tenocytes besides small amounts of chondrocytes (Kannus, 2000). Moderate COL-II expression is observed in vivo in human rotator cuff tendon (Gigante et al., 2004; Martin et al., 2003) and was presently confirmed for cultivated rotator cuff tendon cells.

Increased amounts of chondrocytes can be present in overused tendon (Archambault et al., 2007) or chronic rotator cuff tears: In vivo transdifferentiation was observed in larger rotator cuff tears, especially in tendon stump areas of low fibroblast presence (Fukuda et al., 1990; Matthews 

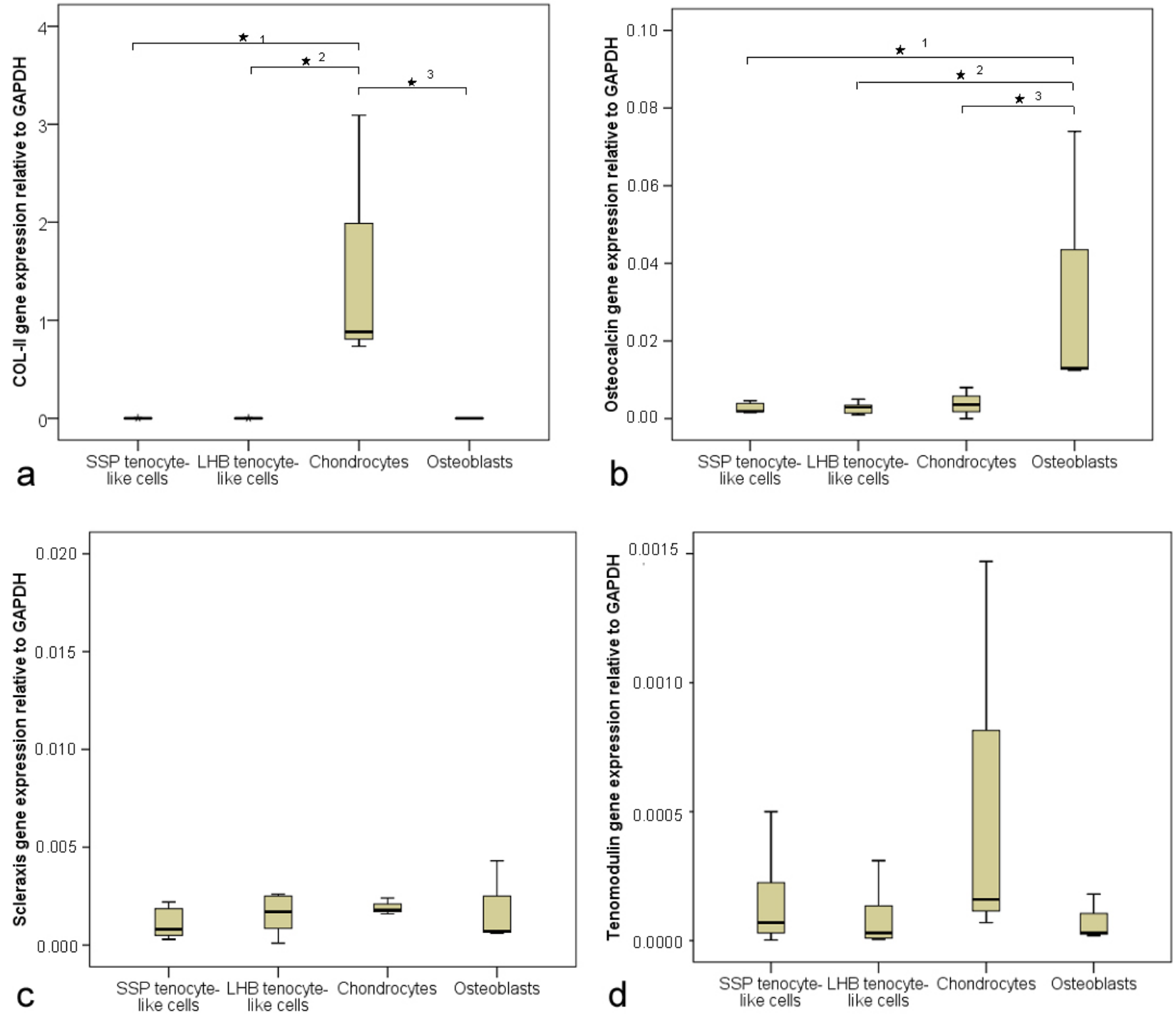

Fig. 4. Real-time quantitative polymerase chain reaction of cartilage, bone and tendon markers relative to GAPDH and respective tissue origin of cell cultures of SSP tenocyte-like cells $(n=11)$, LHB tenocyte-like cells ( $n=7)$, chondrocytes $(\mathrm{n}=3)$ and osteoblasts $(\mathrm{n}=3) ; * p \leq 0.05$. (a) COL-II expression of reference chondrocytes showed significant differences compared to SSP tenocyte-like cells $\left(p^{1}=0.01\right)$, LHB tenocyte-like cells $\left(p^{2}=0.014\right)$ and osteoblasts $\left(p^{3}=0.046\right)$. (b) Osteocalcin expression differed significantly for SSP tenocyte-like cells $\left(p^{1}=0.009\right)$, LHB tenocyte-like cells $\left(p^{2}=0.017\right)$ and chondrocytes $\left(p^{3}=0.05\right)$ compared to reference osteoblasts. (c) Scleraxis expression without significant differences between the cell types compared to reference tenocytes. (d) For tenomodulin expression, chondrocytes served as reference group. No significant differences could be detected.

et al., 2006). Other authors suggested that chondroid metaplasia may be influenced by both compression and tension forces in human rotator cuff prior to complete tear (Gigante et al., 2004). Furthermore, tendon cells isolated from their natural biomechanical surrounding may transdifferentiate into fibrocartilage cell lines in vitro (Ehlers and Vogel, 1998; Jelinsky et al., 2010; SchulzeTanzil et al., 2004).

Present tenocyte-like cells differed from chondrocytes in terms of reduced expression of COL-II while higher COL-I-levels were found. COL-I is the main component of extracellular tendon matrix (Blevins et al., 1997; Kannus, 2000). Its synthesis is increased initially after rotator cuff tendon injury and then decreased with time in chronic tears (Yokota et al., 2005). Tenocyte-like cells presently expressed COL-I. Hence, COL-I cannot be considered tendon specific. Tenocyte-like cells furthermore showed significant differences from osteoblasts in terms of osteocalcin expression, a bone-specific non-collagen protein in the bone matrix.

Cultivation of small amounts of chondrocytes or osteoblasts cannot be ruled out by the present approach. However, tenocyte-like cells in total showed expression patterns significantly different from chondrocyte and osteoblast cultures with regard to characteristic markers. Besides significant differences to other musculoskeletal cell types, several other markers were investigated. Even though these cannot be considered specific, however, their respective presence in tendon was described and hence should be confirmed in vitro. 


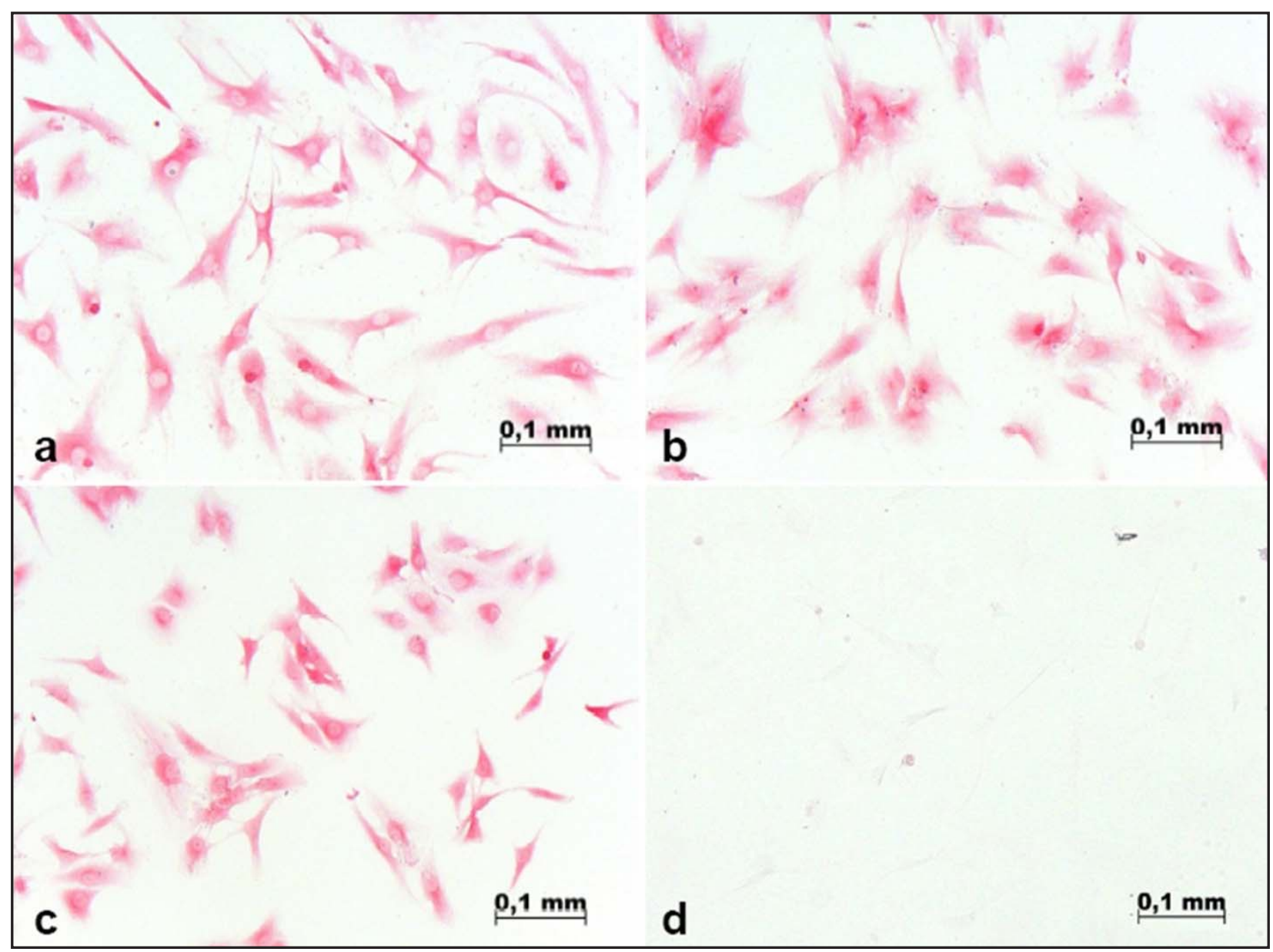

Fig. 5. Immunocytochemical staining for Scleraxis of formaldehyde-fixed (a) SSP tenocyte-like cells, (b) Chondrocytes and (c) Osteoblasts showed comparable intensities. (d) SSP Tenocyte-like cells negative control without primary antibody.

COL-III was expressed by the tenocyte-like cells with a slight decrease compared to osteoblasts. As another component of ECM (Kannus, 2000), COL-III production is increased in tenocytes from ruptured and tendinopathiccompared to intact Achilles tendon (Maffulli et al., 2000). In the present study, tendon material was obtained from torn rotator cuff and expression of COL-III was not compared to intact rotator cuff biopsies to potentially confirm this observation.

The expression profile of COL-III over time during tendon healing was described (Hefti and Stoll, 1995; Takahasih et al., 2002; Yokota et al., 2005), but present amount of COL-III expression does not allow approximation of the time point of rotator cuff tear.

Decorin and biglycan are non-specific proteoglycans in several tissue types such as tendon, cartilage and bone (Rees et al., 2000; Yoon and Halper, 2005). Both were increased initially after experimental tendon detachment (chronic tear model) and then decreased, although Decorin remained elevated from normal for months after injury (Yokota et al., 2005). In the present cell culture study, decorin was expressed lower in both SSP and LHB tenocyte-like cells when compared to chondrocytes. Biglycan was expressed in a comparable quantity for both chondrocytes and tenocyte-like cells while osteoblasts expressed slightly more biglycan. Both markers were detected in the tenocyte-like cells as expected but do not exclusively allow the characterization of tenocyte-like cells.

As a proteoglycan present in fibrocartilage and tendon (Rees et al., 2000; Yoon and Halper, 2005), aggrecan was expressed by both tenocyte-like cell types while slightly higher amounts were seen in chondrocytes. High levels are expressed in compressed regions of tendon and particularly in fibrocartilage, while low levels are expressed in tensional parts (Yoon and Halper, 2005). In vivo, both SSP and LHB tendons are subjected to both traction- and compression forces depending on the position of the humeral head. Osteoblasts expressed aggrecan as described before (Wong et al., 1992).

Tenascin-C is an anti-adhesive ECM protein and present in musculoskeletal regions that are transmitting mechanical forces from one tissue component to another (Jarvinen et al., 2000), such as osteotendinous junctions as well as articular cartilage (Kannus et al., 1998). Isoforms of tenascin-C in degenerated tendon were suggested to potentially stimulate tenocyte proliferation (Riley et al., 1996). The expression of tenascin- $C$ is regulated by mechanical stress (Chiquet-Ehrismann and Tucker, 2004) and is elevated in degenerative SSP tendon (Riley et al., 
Table 2. Overview on human tendon cell markers used in the current literature

\begin{tabular}{|c|c|c|c|}
\hline \multicolumn{2}{|c|}{ Markers/parameter used } & \multirow{2}{*}{ Author/study group } & \multirow{2}{*}{ Tissue origin } \\
\hline Before experiment & After experiment & & \\
\hline morphology & $\begin{array}{l}\text { COL-I, -III, Transforming } \\
\text { Growth Factor } \beta \text { (TGF- } \beta 1)\end{array}$ & (Yang et al., 2004) & $\begin{array}{l}\text { human patellar } \\
\text { tendon }\end{array}$ \\
\hline none & $\begin{array}{l}\text { COL-I, -III, MMP-1, }-3,-13 \text {, } \\
\text { Vascular Endothelial Growth } \\
\text { Factor (VEGF), TGF- } \beta\end{array}$ & (de Mos et al., 2008) & $\begin{array}{l}\text { human hamstring } \\
\text { tendon ( } 3 \text { children) }\end{array}$ \\
\hline morphology & COL-I, -II, -III & (Takahasih et al., 2002) & human rotator cuff \\
\hline none & COL-I, III & (Maffulli et al., 2000) & $\begin{array}{l}\text { human achilles } \\
\text { tendon }\end{array}$ \\
\hline $\begin{array}{l}\text { COL, CD44, } \\
\text { CD90, D7fib }\end{array}$ & COL, CD44, CD90, D7fib & (Scutt et al., 2008) & $\begin{array}{l}\text { human vs. rodent } \\
\text { patellar tendon and } \\
\text { anterior cruciate } \\
\text { ligament (ACL) }\end{array}$ \\
\hline morphology & $\begin{array}{l}\text { COL-I, -II, scleraxis, } \\
\text { fibronectin, proteoglycan, } \beta 1 \text { - } \\
\text { integrin }\end{array}$ & $\begin{array}{c}\text { (Schulze-Tanzil et al., } \\
\text { 2004) }\end{array}$ & $\begin{array}{l}\text { human finger flexor } \\
\text { tendon (of one } \\
\text { donor) vs. cartilage } \\
\text { tissue }\end{array}$ \\
\hline none & $\begin{array}{l}\text { haematoxylin and eosin } \\
\text { staining, } \\
\text { polarized microscopy (collagen } \\
\text { maturation level); mechanical } \\
\text { properties }\end{array}$ & (Wang et al., 2008) & $\begin{array}{l}\text { human foetal } \\
\text { extensor tendon }\end{array}$ \\
\hline COL-I, Decorin & COL-I, Decorin & (Kardestuncer et al., 2006) & $\begin{array}{l}\text { human hamstring } \\
\text { tendon }\end{array}$ \\
\hline COL-I & $\begin{array}{l}\text { COL-I, Hepatocyte Growth } \\
\text { Factor (HGF), VEGF, TGF- } 31 \\
\end{array}$ & (Anitua et al., 2006) & human ACL \\
\hline morphology & COL-I, Actin filament, Vinculin & (Li et al., 2008) & $\begin{array}{l}\text { human patellar } \\
\text { tendon }\end{array}$ \\
\hline none & $\begin{array}{l}\text { None (adhesion and } \\
\text { proliferation rate) }\end{array}$ & (Mazzocca et al., 2007) & $\begin{array}{l}\text { human tendon } \\
\text { tissue vs. bone } \\
\text { tissue }\end{array}$ \\
\hline COL-I & None & (Gumina et al., 2009) & human rotator cuff \\
\hline none & $\begin{array}{l}\text { COL-I, MMP-2, }-8,-12,-13, \\
\text { Tissue Inhibitor of } \\
\text { Metalloproteinase (TIMP), Sox } 9\end{array}$ & (Tempfer et al., 2009) & human rotator cuff \\
\hline $\begin{array}{l}\text { Tenomodulin, } \\
\text { Thrombospondin } 4\end{array}$ & & (Jelinsky et al., 2010) & $\begin{array}{l}\text { human tendon } \\
\text { tissue }\end{array}$ \\
\hline \multicolumn{2}{|c|}{$\begin{array}{l}\text { COL-I, - III, decorin, COMP, aggrecan, elastin, } \\
\text { scleraxis, Sox } 9\end{array}$} & (Stoll et al., 2010) & $\begin{array}{l}\text { human hamstring } \\
\text { tendon }\end{array}$ \\
\hline \multicolumn{2}{|c|}{ COL-I, -III, decorin } & (Yao et al., 2006) & $\begin{array}{l}\text { human achilles } \\
\text { tendon }\end{array}$ \\
\hline \multicolumn{2}{|c|}{ COL-I, -III, fibronectin, MMP-12, TIMP-1 } & (Almarza et al., 2008) & $\begin{array}{l}\text { Human medial } \\
\text { collateral ligament } \\
(\mathrm{MCL}), \mathrm{ACL}, \\
\text { patellar tendon } \\
\end{array}$ \\
\hline
\end{tabular}

1996). Compared to tenocyte-like cell cultures, slightly elevated expression of tenascin $\mathrm{C}$ was found in chondrocyte and osteoblast controls.

Several approaches to establish effective primers for scleraxis were unsuccessful: no products were obtained or non-desired dimers were formed, respectively. The targeted Scleraxis-gene is rather short compared to other gene-sequences (with only about 2600 bases) and has just two exons which reduces the chance of designing a reliable primer. Using a commercially available primer, comparable amounts of scleraxis were obtained for tenocyte-like cells, chondrocytes and osteoblasts in both RT-PCR and in immunocytochemical staining. These findings might suggest that scleraxis is non-specific for tendon which was supported by its detection in several other musculoskeletal tissues (Edom-Vovard et al., 2002; Jelinsky et al., 2010). In contrast, other authors reported on Scleraxis as a tendonspecific gene (Schweitzer et al., 2001) which regulates the expression of tenomodulin (Shukunami et al., 2006). Significant differences in scleraxis expression were reported between human chondrocyte and flexor tendon cells of one adult donor. However, a 3D-culture was used which potentially may explain different expression patterns (Schulze-Tanzil et al., 2004). 
Tenomodulin is a transmembrane glycoprotein which is non-specific, but mainly expressed in tendon and ligament (Shukunami et al., 2006). Other authors claimed tenomodulin as a selective tendon gene (Jelinsky et al., 2010). Its high expression compared to different other tissues, however, is fading when cells are cultured twodimensionally (Jelinsky et al., 2010). The tenocyte-like cells in the present study were cultured in monolayers, which may explain its low expression. Furthermore, moderate expression of tenomodulin was reported in cartilage and bone (Jelinsky et al., 2010), which is in accordance with the present low expression in chondrocytes and osteoblasts.

Brune et al. analyzed tendon cells from intact vs. torn ligament and observed differences in expression patterns but similar behaviour when seeded for tissue engineering (Brune et al., 2007). Other authors suggested fibroblast cultures from healing instead of intact tendon to be more appropriate for studying cellular tendon regeneration (Fu et al., 2008). In contrast to other authors focusing on intact human rotator cuff material (Tempfer et al., 2009), donor material for the present study was obtained from torn rotator cuff. This cannot be classified as healing but was submitted to structural and biomechanical changes prior to biopsy.

Indeed, intact tendon tissue may not reflect the biological situation in chronic rotator cuff tears as assessed during surgical reconstruction. The present analysis of torn human rotator cuff tissue was in accordance with expression profiles in rodent experiments on chronic cuff tear models (Yokota et al., 2005).

\section{Study limitations}

As a limitation of the present study, no possible correlations of the investigated tenocyte-like cell culture characteristics with respective patient subgroups were investigated. A prospective study in a rather small series of cases was performed to generally analyze whether or not a human rotator cuff cell culture can be established. As a further weakness, neither 3D-cell cultures nor biomechanical stimulation of obtained cell cultures were investigated. We hypothesize that tenocyte-like cells grown under different culture conditions on scaffolds could show a variable phenotype compared to monolayer culture as shown by other publications (Theisen et al., 2010; Stoll et al., 2010).

\section{Conclusions}

The present study describes the successful cultivation of human rotator cuff cells. Characterization of these rotator cuff cells showed an expression pattern of different gene markers that is unique for these cell types and in parts significantly different to osteoblasts and chondrocytes.

As a conclusion of our results it seems to be important to look at the collective expression profile of the tenocytelike cells. COL-I is the most important protein for tenocytelike cells and should be highly expressed. COL-III, biglycan, decorin, and tenascin $\mathrm{C}$ should also be expressed while COL-II and osteocalcin expression should be present just in low amounts.
Since no specific gene- or protein markers for tendon are known so far, the present approach represents a description as close as possible based on currently discussed markers. This characterization is necessary for further studies on the biology and stimulation of tendon cells in order to optimize therapy outcome in rotator cuff cells.

\section{Acknowledgments}

The authors gratefully thank the European Society for Shoulder and Elbow Surgery (ESSES/SECEC, a non-profit organization) for generously providing a research grant. We thank Dr. Schulze-Tanzil and colleagues for the discussion regarding the tendon cell culture. We furthermore thank Dr. Ringe and colleagues for kindly providing primal chondrocyte cell cultures serving as a control.

\section{References}

Almarza AJ, Augustine SM, Woo SL (2008) Changes in gene expression of matrix constituents with respect to passage of ligament and tendon fibroblasts. Ann Biomed Eng 36: 1927-1933.

Angel MJ, Sgaglione NA, Grande DA (2006) Clinical applications of bioactive factors in sports medicine: current concepts and future trends. Sports Med Arthrosc 14: 138145.

Anitua E, Sanchez M, Nurden AT, Zalduendo M, de la Fuente M, Orive G, Azofra J, Andia I (2006) Autologous fibrin matrices: a potential source of biological mediators that modulate tendon cell activities. J Biomed Mater Res A 77: 285-293.

Archambault JM, Jelinsky SA, Lake SP, Hill AA, Glaser DL, Soslowsky LJ (2007) Rat supraspinatus tendon expresses cartilage markers with overuse. J Orthop Res 25: 617-624.

Batten ML, Hansen JC, Dahners LE (1996) Influence of dosage and timing of application of platelet-derived growth factor on early healing of the rat medial collateral ligament. J Orthop Res 14: 736-741.

Bayne O, Bateman J (1984) Long term results of surgical repair of full thickness rotator cuff tears. In: Surgery of the shoulder (Bateman J, Welsh R, eds), Mosby, Philadelphia, pp 167-171.

Baysal D, Balyk R, Otto D, Luciak-Corea C, Beaupre L (2005) Functional outcome and health-related quality of life after surgical repair of full-thickness rotator cuff tear using a mini-open technique. Am J Sports Med 33: 1346-1355.

Bishop J, Klepps S, Lo IK, Bird J, Gladstone JN, Flatow EL (2006) Cuff integrity after arthroscopic versus open rotator cuff repair: a prospective study. J Shoulder Elbow Surg 15: 290-299.

Blevins FT, Djurasovic M, Flatow EL, Vogel KG (1997) Biology of the rotator cuff tendon. Orthop Clin North Am 28: 1-16.

Boileau P, Brassart N, Watkinson DJ, Carles M, Hatzidakis AM, Krishnan SG (2005) Arthroscopic repair 
of full-thickness tears of the supraspinatus: does the tendon really heal? J Bone Joint Surg Am 87: 1229-1240.

Brune T, Borel A, Gilbert TW, Franceschi JP, Badylak SF, Sommer P (2007) In vitro comparison of human fibroblasts from intact and ruptured ACL for use in tissue engineering. Eur Cell Mater 14: 78-90

Chang J, Thunder R, Most D, Longaker MT, Lineaweaver WC (2000) Studies in flexor tendon wound healing: neutralizing antibody to TGF-betal increases postoperative range of motion. Plast Reconstr Surg 105: 148-155.

Chiquet-Ehrismann R, Tucker RP (2004) Connective tissues: signalling by tenascins. Int J Biochem Cell Biol 36: 1085-1089.

Chuen FS, Chuk CY, Ping WY, Nar WW, Kim HL, Ming CK (2004) Immunohistochemical characterization of cells in adult human patellar tendons. J Histochem Cytochem 52: 1151-1157.

Cole BJ, McCarty LP, 3rd, Kang RW, Alford W, Lewis PB, Hayden JK (2007) Arthroscopic rotator cuff repair: prospective functional outcome and repair integrity at minimum 2-year follow-up. J Shoulder Elbow Surg 16: 579-585.

Costa MA, Wu C, Pham BV, Chong AK, Pham HM, Chang J (2006) Tissue engineering of flexor tendons: optimization of tenocyte proliferation using growth factor supplementation. Tissue Eng 12: 1937-1943.

De Mos M, Van der Windt AE, Jahr H, Van Schie HT, Weinans H, Verhaar JA, Van Osch GJ. (2008) Can plateletrich plasma enhance tendon repair? A cell culture study. Am J Sports Med 36: 1171-1178.

Edom-Vovard F, Schuler B, Bonnin MA, Teillet MA, Duprez D (2002) Fgf4 positively regulates scleraxis and tenascin expression in chick limb tendons. Dev Biol 247: 351-366.

Ehlers TW, Vogel KG (1998) Proteoglycan synthesis by fibroblasts from different regions of bovine tendon cultured in alginate beads. Comp Biochem Physiol A Mol Integr Physiol 121: 355-363.

Flatow EL (1996) Tendon-healing in goats. J Bone Joint Surg Am 78: 1785-1786.

Fu SC, Cheuk YC, Chan KM, Hung LK, Wong MW (2008) Is cultured tendon fibroblast a good model to study tendon healing? J Orthop Res 26: 374-383.

Fukuda H, Hamada K, Yamanaka K (1990) Pathology and pathogenesis of bursal-side rotator cuff tears viewed from en bloc histologic sections. Clin Orthop Relat Res (254): 75-80.

Gerber C, Schneeberger AG, Beck M, Schlegel U (1994) Mechanical strength of repairs of the rotator cuff. J Bone Joint Surg Br 76: 371-380.

Gigante A, Marinelli M, Chillemi C, Greco F (2004) Fibrous cartilage in the rotator cuff: A pathogenetic mechanism of tendon tear? J Shoulder Elbow Surg 13: 328-332.

Goutallier D, Postel JM, Bernageau J, Lavau L, Voisin MC (1994) Fatty muscle degeneration in cuff ruptures. Pre- and postoperative evaluation by CT Scan Clin Orthop Relat Res (304): 78-83.

Gumina S, Patti AM, Vulcano A, Della Rocca C, Postacchini F (2009) Culture of human rotator cuff cells on orthobiologic support (porcine small intestinal submucosa). Musculoskelet Surg 93 Suppl 1: S65-70.

Hefti F, Stoll TM (1995) [Healing of ligaments and tendons]. Orthopäde 24: 237-245.

Hsu C, Chang J (2004) Clinical implications of growth factors in flexor tendon wound healing. J Hand Surg [Am] 29: 551-563.

Itaya T, Kagami H, Okada K, Yamawaki A, Narita Y, Inoue M, Sumita Y, Ueda M (2009) Characteristic changes of periodontal ligament-derived cells during passage. J Periodontal Res 44: 425-433.

Jarvinen TA, Kannus P, Jarvinen TL, Jozsa L, Kalimo $\mathrm{H}$, Jarvinen M (2000) Tenascin-C in the pathobiology and healing process of musculoskeletal tissue injury. Scand J Med Sci Sports 10: 376-382.

Jelinsky SA, Archambault J, Li L, Seeherman H (2010) Tendon-selective genes identified from rat and human musculoskeletal tissues. J Orthop Res 28: 289-297.

Kannus P (2000) Structure of the tendon connective tissue. Scand J Med Sci Sports 10: 312-320.

Kannus P, Jozsa L, Järvinen TA, Järvinen TL, Kvist M, Natri A, Järvinen M (1998) Location and distribution of non-collagenous matrix proteins in musculoskeletal tissues of rat. Histochem J 30: 799-810.

Kardestuncer T, McCarthy MB, Karageorgiou V, Kaplan D, Gronowicz G (2006) RGD-tethered silk substrate stimulates the differentiation of human tendon cells. Clin Orthop Relat Res 448: 234-239.

Lafosse L, Brozska R, Toussaint B, Gobezie R (2007) The outcome and structural integrity of arthroscopic rotator cuff repair with use of the double-row suture anchor technique. J Bone Joint Surg Am 89: 1533-1541.

Lee J, Green MH, Amiel D (1995) Synergistic effect of growth factors on cell outgrowth from explants of rabbit anterior cruciate and medial collateral ligaments. J Orthop Res 13: 435-441.

Li F, Li B, Wang QM, Wang JH (2008) Cell shape regulates collagen type I expression in human tendon fibroblasts. Cell Motil Cytoskeleton 65: 332-341.

Lorbach O, Bachelier F, Vees J, Kohn D, Pape D (2008) Cyclic loading of rotator cuff reconstructions: single-row repair with modified suture configurations versus doublerow repair. Am J Sports Med 36: 1504-1510.

Maffulli N, Ewen SW, Waterston SW, Reaper J, Barrass V (2000) Tenocytes from ruptured and tendinopathic achilles tendons produce greater quantities of type III collagen than tenocytes from normal achilles tendons. An in vitro model of human tendon healing. Am J Sports Med 28: 499-505.

Maffulli N, Moller HD, Evans CH (2002) Tendon healing: can it be optimised? Br J Sports Med 36: 315316.

Mahar A, Tamborlane J, Oka R, Esch J, Pedowitz RA (2007) Single-row suture anchor repair of the rotator cuff is biomechanically equivalent to double-row repair in a bovine model. Arthroscopy 23: 1265-1270.

Martin JA, Mehr D, Pardubsky PD, Buckwalter JA (2003) The role of tenascin-C in adaptation of tendons to compressive loading. Biorheology 40: 321-329.

Marui T, Niyibizi C, Georgescu HI, Cao M, Kavalkovich KW, Levine RE, Woo SL (1997) Effect of 
growth factors on matrix synthesis by ligament fibroblasts. J Orthop Res 15: 18-23.

Matthews TJ, Hand GC, Rees JL, Athanasou NA, Carr AJ (2006) Pathology of the torn rotator cuff tendon. Reduction in potential for repair as tear size increases. $\mathrm{J}$ Bone Joint Surg Br 88: 489-495.

Mazzocca AD, McCarthy MB, Arciero C, Jhaveri A, Obopilwe E, Rincon L, Wyman J, Gronowicz GA, Arciero RA(2007) Tendon and bone responses to a collagen-coated suture material. J Shoulder Elbow Surg 16: S222-230.

Molloy T, Wang Y, Murrell G (2003) The roles of growth factors in tendon and ligament healing. Sports Med 33: 381-394.

Neumann K, Endres M, Ringe J, Flath B, Manz R, Häupl T, Sittinger M, Kaps C (2007) BMP7 promotes adipogenic but not osteo-/chondrogenic differentiation of adult human bone marrow-derived stem cells in highdensity micro-mass culture. J Cell Biochem 102: 626-637.

Patte D (1990) Classification of rotator cuff lesions. Clin Orthop Relat Res (254): 81-86.

Pauly S, Kieser B, Schill A, Gerhardt C, Scheibel M (2010) Biomechanical comparison of four double-row Suture Bridging rotator cuff repair techniques using different medial row configurations. Arthroscopy, in press.

Rahaman MN, Mao JJ (2005) Stem cell-based composite tissue constructs for regenerative medicine. Biotechnol Bioeng 91: 261-284.

Rees SG, Flannery CR, Little CB, Hughes CE, Caterson B, Dent CM (2000) Catabolism of aggrecan, decorin and biglycan in tendon. Biochem J 350: 181-188.

Riley GP, Harrall RL, Cawston TE, Hazleman BL, Mackie EJ (1996) Tenascin-C and human tendon degeneration. Am J Pathol 149: 933-943.

Rios CG, McCarthy MB, Arciero C, Spang JT, Arciero R, Mazzocca AD (2007) Biologics in shoulder surgery: The role of adult mesenchymal stem cells in tendon repair. Techn Orthopaed 22: 2-9.

Robey PG, Termine JD (1985) Human bone cells in vitro. Calcif Tissue Int 37: 453-460.

Salingcarnboriboon R, Yoshitake H, Tsuji K, Obinata M, Amagasa T, Nifuji A, Noda M. (2003) Establishment of tendon-derived cell lines exhibiting pluripotent mesenchymal stem cell-like property. Exp Cell Res 287: 289-300.

Schulze-Tanzil G, Mobasheri A, Clegg PD, Sendzik J, John T, Shakibaei M (2004) Cultivation of human tenocytes in high-density culture. Histochem Cell Biol 122: 219-228.

Schweitzer R, Chyung JH, Murtaugh LC, Brent AE, Rosen V, Olson EN, Lassar A, Tabin CJ (2001) Analysis of the tendon cell fate using Scleraxis, a specific marker for tendons and ligaments. Development 128: 3855-3866.

Scutt N, Rolf C, Scutt A (2008) Tissue specific characteristics of cells isolated from human and rat tendons and ligaments. J Orthop Surg 3:32.

Severud EL, Ruotolo C, Abbott DD, Nottage WM (2003) All-arthroscopic versus mini-open rotator cuff repair: A long-term retrospective outcome comparison. Arthroscopy 19: 234-238.
Shukunami C, Takimoto A, Oro M, Hiraki Y (2006) Scleraxis positively regulates the expression of tenomodulin, a differentiation marker of tenocytes. Dev Biol 298: 234-247.

Stoll C, John T, Endres M, Rosen C, Kaps C, Kohl B, Sittinger M, Ertel W, Schulze-Tanzil G (2010) Extracellular matrix expression of human tenocytes in three-dimensional air-liquid and PLGA cultures compared with tendon tissue: Implications for tendon tissue engineering. J Orthop Res, in press.

Takahasih S, Nakajima M, Kobayashi M, Wakabayashi I, Miyakoshi N, Minagawa H, Itoi E (2002) Effect of recombinant basic fibroblast growth factor (bFGF) on fibroblast-like cells from human rotator cuff tendon. Tohoku J Exp Med 198: 207-214.

Tempfer H, Gehwolf R, Lehner C, Wagner A, Mtsariashvili M, Bauer HC, Resch H, Tauber M (2009) Effects of crystalline glucocorticoid triamcinolone acetonide on cultured human supraspinatus tendon cells. Acta Orthop 80: 357-362..

Theisen C, Fuchs-Winkelmann S, Knappstein K, Efe T, Schmitt J, Paletta JR, Schofer MD (2010) Influence of nanofibers on growth and gene expression of human tendon derived fibroblast. Biomed Eng Online 9: 9.

Thomopoulos S, Harwood FL, Silva MJ, Amiel D, Gelberman RH (2005) Effect of several growth factors on canine flexor tendon fibroblast proliferation and collagen synthesis in vitro. J Hand Surg [Am] 30: 441-447.

Thomopoulos S, Zaegel M, Das R, Harwood FL, Silva MJ, Amiel D, Sakiyama-Elbert S, Gelberman RH (2007) PDGF-BB released in tendon repair using a novel delivery system promotes cell proliferation and collagen remodeling. J Orthop Res 25: 1358-1368.

Wang B, Liu W, Zhang Y, Jiang Y, Zhang WJ, Zhou G, Cui L, Cao Y (2008) Engineering of extensor tendon complex by an ex vivo approach. Biomaterials 29: 29542961.

Wolf EM, Pennington WT, Agrawal V (2004) Arthroscopic rotator cuff repair: 4- to 10-year results. Arthroscopy 20: 5-12.

Wong M, Lawton T, Goetinck PF, Kuhn JL, Goldstein SA, Bonadio J (1992) Aggrecan core protein is expressed in membranous bone of the chick embryo. Molecular and biomechanical studies of normal and nanomelia embryos. J Biol Chem 267: 5592-5598.

Yang G, Crawford RC, Wang JH (2004) Proliferation and collagen production of human patellar tendon fibroblasts in response to cyclic uniaxial stretching in serum-free conditions. J Biomech 37: 1543-1550.

Yao L, Bestwick CS, Bestwick LA, Maffulli N, Aspden RM (2006) Phenotypic drift in human tenocyte culture. Tissue Eng 12: 1843-1849.

Yokota A, Gimbel JA, Williams GR, Soslowsky LJ (2005) Supraspinatus tendon composition remains altered long after tendon detachment. J Shoulder Elbow Surg 14: 72S-78S.

Yoon JH, Halper J (2005) Tendon proteoglycans: biochemistry and function. J Musculoskelet Neuronal Interact 5: 22-34. 


\section{Discussion with Reviewers}

Reviewer I: Which expression profile and level will give evidence that tenocytes were isolated and cultured. At what level do you think it is better to discharge a culture?

Authors: To answer this question it seems to be important to look at the collective expression profile of the tenocytelike cells. COL-I is the most important protein for tenocytelike cells and should be highly expressed. COL-III, biglycan, decorin, and tenascin $\mathrm{C}$ should also be expressed while COL-II and osteocalcin expression should not be present. It is difficult to define concrete values for the expression level but on the basis of the presented results cell cultures with a higher relative COL-II and osteocalcin expression to GAPDH than 0.01 should not be considered as tendon-like cell cultures.

Reviewer II: Could you justify the use of monolayer cultures with all the attendant problems of dedifferentiation - this is stated in the manuscript but reasons for using this method would be useful to know here. Please comment! Authors: To isolate cells from the native tendon it is necessary to culture them in monolayer and no other methods are known to do this in 3D culture. For further expanding of the isolated cells, with regard to very little native material we could obtain and the small amounts of tendon-like cells in the material, a monolayer culture seems the best method to ensure growth of cells as quickly as possible. A second important fact is that normal microscopic cell evaluation is impossible in $3 \mathrm{D}$ culture, for example in scaffolds. The morphology of the tenocytelike cells was also important for the characterization and to estimate the condition of the cells. It is known that the tenocyte-like cells expanded in monolayer show an unstable phenotype and a tendency to dedifferentiate, but there is no evidence that this can be avoided when cells are cultured in 3D. For example, Stoll et al. also demonstrated phenotypic differences of tenocyte-like cells cultured on scaffolds and in high-density culture compared to native tendon and with the growth of the culture (Stoll et al., 2010; text reference).

Reviewer II: Why was immunohistochemistry carried out for scleraxis and not for the other proteins?

Authors: As already mentioned, scleraxis is discussed in the literature as one possible tendon specific marker. As only low scleraxis expression was found at the RNA-level on tenocyte-like cells we decided to investigate the expression of scleraxis also on the protein level.

Reviewer II: Your controls not adequate: you should have used serum or immunoglobulins of the species of the primary antibody, as well as a control excluding the first antibody. Also, positive controls would have been useful. Authors: We agree with the reviewer that more controls could have been performed. We just used the first antibody control to exclude the unspecific binding of the secondary antibody. In order to test the specificity of the primary antibody by precipitation, a scleraxis protein would be necessary. Since there is no scleraxis protein available, this control could not be carried out.
Reviewer II: The rotator cuff-derived cells appear to do very little - all parameters give low values. Given that the rotator cuff cells routinely give low values compared to the other cell types, I would be concerned about the culture conditions being appropriate for the cells.

Authors: We respectfully disagree that rotator cuff cells "routinely give low values" when compared to the other cell types. Some relevant markers were expected to give low values in the tenocytes when compared to other cell types, i.e., expression of COL-II (compared to chondrocytes) or osteocalcin (compared to osteoblasts). Unfortunately, the current literature does not allow a quantitative comparison of the present results to other studies elucidating different expression profiles between human rotator cuff tendon-like cells, chondrocytes and osteoblasts. However, we do not assume that these differences necessarily represent inappropriate culture conditions. With respect to the second part of the reviewer's suggestion, indeed there is no evidence that chosen culture conditions are inadequate for these cells. When searching the literature, different culture media were used for tenocyte-like cells. Other research groups also used DMEM (Guoguang et al., 2004), HAM's F12 (Klein et al., 2002) or DMEM/HAM's F12 (Tsai et al., 2003) medium without supplements such as ascorbate. We followed the decision to culture the cells this way and did not observe any problems with cell viability or activity.

Reviewer II: I am also unconvinced by the scleraxis labels; as indicated above I think an extra control is necessary, along with some positive controls. It seems odd that all cells should stain with a very low level of expression as measured by supposedly high sensitivity qPCR methodology should label, along with cell types that are not generally associated with expression of this molecule. Authors: Two different methods to analyse the scleraxis expression and production were performed. By quantitative RT-PCR we found low levels of scleraxis. Using this quantitative method we did not expect high levels of this transcription factor as seen for all matrix proteins in this study. In contrast to RT- PCR, immunocytochemistry is no quantitative method and can only visualize whether or not a protein is present. Therefore, we suggest that the unequal results are not caused by wrong protocols but are normal variances obtained from methods that are different in principle.

Reviewer II: There is no doubt that you have cultured cells from the rotator cuff tendon that are different from chondrocytes and osteoblasts, but it is difficult to draw conclusions as to their behaviour in culture as they seem to be doing very little. Perhaps supplementation with ascorbate, as you do for osteoblasts, might help osteoblasts seem to be the most active cells in your experiments. It is very difficult to make comparisons between these cell types given the differences in culture medium supplements.

Authors: We agree that differences in cell culture supplements like ascorbate could influence the matrix expression. But no comparative study on tenocytes was found to prove this. Ibold et al. showed the influence of 
different ascorbate supplementations on chondrocyte pellet cultures. $100 \mu \mathrm{M}$ L-ascorbate-2-phosphate (we used 50 $\mu \mathrm{M})$ resulted in decreased COL-I expression at the beginning of the culture and slightly increased COL-II and aggrecan expression (Ibold et al., 2009). Another study on mesenchymal stem cells revealed that ascorbate supplementation $(0-500 \mu \mathrm{M})$ had almost no effect on growth and proliferation until passage 3 (Choi et al., 2008). Son et al. demonstrated that ascorbate supplementation (60 and $125 \mu \mathrm{M})$ did not affect the collagen expression (Son et al., 2007). To rule out an effect of the different culture conditions on matrix expression, we agree that it would have been better to culture all cells with the same supplementations. But with respect to the mentioned studies we would not expect a marked difference in expression profiles. We therefore think that our comparison is reasonable.

\section{Additional References}

Choi KM, Seo YK, Yoon HH, Song KY, Kwon SY, Lee HS, Park JK (2008) Effect of ascorbic acid on bone marrow-derived mesenchymal stem cell proliferation and differentiation. J Biosci Bioeng 105: 586-594.

Guoguang Y, Crawford RC, Wang JHC (2004) Proliferation and collagen production of human patellar tendon fibroblasts in response to cyclic uniaxial stretching. J Biomech 37: 1543-1550.

Ibold Y, Lübke C, Pelz S, Augst H, Kaps C, Ringe J, Sittinger M (2009) Effect of different ascorbate supplementations on in vitro cartilage formation in porcine high-density pellet cultures. Tissue Cell 41: 249-256.

Klein MB, Yalamanchi N, Pham H, Longaker MT, Chang J (2002) Flexor tendon healing in vitro: effects of TGF-beta on tendon cell collagen production. J Hand Surg 27A: 615-620.

Son E, Do H, Joo HM, Pyo S (2007) Induction of alkaline phosphatase activity by L-ascorbic acid in human osteoblastic cells: a potential role for CK2 and Ikaros. Nutrition 23: 745-753.

Tsai AD, Yeh LC, Lee JC (2003) Effects of osteogenic protein-1 (OP-1, BMP-7) on gene expression in cultured medial collateral ligament cells. J Cell Biochem 90: 777 791. 